\title{
Serum endocan levels can predict malignancy of thyroid: a prospective clinical study
}

\section{Serum endokan seviyeleri tiroid malignitesini tahmin edebilir: prospektif bir klinik çalışma}

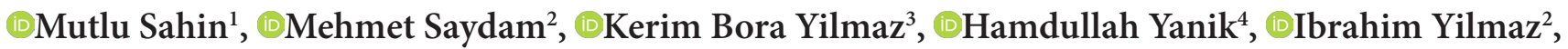 \\ ๑Gorkem Gundogan ${ }^{2}, \oplus$ Cem Azili ${ }^{2}, \oplus$ Melih Akinci $^{3}, \oplus$ Mehmet Ali Gulcelik $^{3}$ \\ ${ }^{1}$ Department of General Surgery, University of Health Sciences, Ankara Kecioren Training and Research Hospital, Ankara, Turkey \\ ${ }^{2}$ Department of General Surgery, University of Health Sciences, Ankara Diskapi Yildirim Beyazit Training and Research Hospital, Ankara, Turkey \\ ${ }^{3}$ Department of General Surgery, University of Health Sciences, Ankara Gulhane Training and Research Hospital, Ankara, Turkey \\ ${ }^{4}$ Department of Basic Oncology, Cancer Institute, Hacettepe University, Ankara, Turkey.
}

Cite this article as/Bu makaleye atıf için: Şahin M, Saydam M, Yllmaz KB, et al. Serum endocan levels can predict malignancy of thyroid: a prospective clinical study. Anatolian Curr Med J 2020; 2(4); 117-122.

\begin{abstract}
Aim: The differential diagnosis of benign and malignant diseases of the thyroid is important in borderline malignancies and malignancies that have not been diagnosed with biopsy. This study aimed to determine endocan molecule levels in patients with thyroid cancer, nodular goiter and thyroiditis. Thus, it was aimed to determine the availability of the endocan molecule in the differential diagnosis of thyroid diseases.

Material and Method: The study was conducted between March 1, 2018 and August 1, 2018. During this period, patients who were scheduled for surgery due to thyroid disease and wanted to participate in the study voluntarily were included in the study. A prospective, cross-sectional clinical trial was designed. Patients included in the study were divided into four groups, according to their pathology report results; Group 1: Papillary thyroid cancer (PTC), Group 2: Multinodular goiter on thyroiditis background, Group 3: Multinodular goiter (MNG), Group 4: Follicular thyroid cancer (FTC).

Results: A total of 72 patients were included in the study. Multiple analysis comparing the four groups, showed no statistically significant difference between the groups $(p>0.050)$. When the benign and malignant patient groups were compared, endocan levels were found to be statistically significantly higher in the malignant group $(\mathrm{p}=0.0375)$. When thyroid carcinoma groups were compared among themselves, the endocan level was detected to be higher in FTC, compared to PTC ( $\mathrm{p}=0.047)$.

Conclusion: The level of "endocan" was observed to increase in malignant thyroid diseases. This was particularly so in FTC, which shows spreading via the hematogenous route. This is an encouraging sign that the "endocan" molecule can be used as a general tumor marker. However, prospective additional studies with large randomized series are needed.
\end{abstract}

Keywords: Thyroid carcinoma, thyroid nodule, thyroiditis, goiter

\section{ÖZ}

Amaç: Tiroidin iyi huylu ve kötü huylu hastalıklarının ayırıcı tanısı, biyopsi ile tanı konulmamış borderline malignitelerde ve malignitelerde önemlidir. Bu çalışmada tiroid kanseri, nodüler guatr ve tiroiditli hastalarda endokan molekül düzeylerinin belirlenmesi amaçlanmıştır. Böylelikle tiroid hastalıklarının ayırıcı tanısında endokan molekülünün kullanılabilirliğinin belirlenmesi amaçlandı.

Gereç ve Yöntem: Çalışma, 1 Mart 2018 ile 1 Ağustos 2018 tarihleri arasında gerçekleştirildi. Bu süre içerisinde tiroid hastalığı nedeniyle ameliyatı planlanıp çalışmaya gönüllü olarak katılmak isteyen hastalar çalışmaya dahil edildi. Prospektif, kesitsel bir klinik çalışma tasarlandı. Çalışmaya dahil edilen hastalar patoloji raporu sonuçlarına göre dört gruba ayrıldı; Grup 1: Papiller tiroid kanseri (PTK), Grup 2: Tiroidit zemininde multinodüler guatr, Grup 3: Multinodüler guatr (MNG), Grup 4: Foliküler tiroid kanseri (FTK).

Bulgular: Çalışmaya toplam 72 hasta dahil edildi. Dört grubu karşılaştıran çoklu analizde, gruplar arasında istatistiksel olarak anlamlı bir fark görülmedi $(p>0,050)$. Benign ve malign hasta grupları karşılaştııldığında endokan düzeyleri malign grupta istatistiksel olarak anlamlı yüksek bulundu ( $\mathrm{p}=0,0375)$. Tiroid karsinom grupları kendi aralarında karşılaştırıldığında endokan düzeyinin FTK’nde PTK’ne göre daha yüksek olduğu tespit edildi $(\mathrm{p}=0,047)$.

Sonuç: Malign tiroid hastalıklarında “endokan” düzeyinin arttığı gözlendi. Bu özellikle hematojen yolla yayılım gösteren FTK’nde daha fazlaydı. Bu, "endokan” molekülünün genel bir tümör belirteci olarak kullanılabileceğine dair cesaret verici bir işarettir. Bununla birlikte, geniş randomize serilerle ileriye dönük ek çalı̧malara ihtiyaç vardır.

Anahtar Kelimeler: Tiroid karsinomu, tiroid nodülü, tiroidit, guatr 


\section{INTRODUCTION}

Malignancy, is the leading indicator for thyroid gland surgery. Further to this, a large goiter, cosmetic causes, nodules suspected of malignancy and toxic nodules may also indicate the need for surgery. It has been observed that $19-68 \%$ of individuals randomly selected and tested with high-resolution ultrasound, have thyroid nodules (1). While nodular disease of the thyroid is common, malignancy of the thyroid occurs in only $7-15 \%$ of the nodules (2).

Papillary thyroid cancer (PTC) is the most common thyroid cancer and constitutes approximately $80 \%$ of thyroid cancers. In all age groups, apart from childhood, it is observed to be three times more frequent in females than in males (3). Papillary tumors are inclined to invade the lymphatics, with a lower probability of invasion of blood vessels. Follicular thyroid carcinoma (FTC) is the second most common after PTC. It accounts for about $10 \%$ of thyroid cancers. One of the most important differences that distinguishes FTC from PTC, is that it is more likely to invade through blood vessels, rather than invade the lymphatics such as in papillary cancer.

Many methods have been determined in the differential diagnosis of thyroid diseases. Thyroid function studies, thyroid-stimulating hormone (TSH) test, thyroid ultrasound and fine-needle aspiration biopsy (FNAB) should be considered for the diagnosis of thyroid carcinoma. The serum level of carcinoembryonic antigen (CEA) can be measured, however, the implications of an elevated CEA level are not specific. FNAB is considered the best first-line diagnostic procedure for a thyroid nodule.

"Endocan", a dermatan sulfate proteoglycan molecule with a molecular weight of $50 \mathrm{kDa}$, was redefined and cloned by Lassalle et al. in 1996 and is synthesized from activated vascular endothelial cells (4). Many studies have shown that the endocan molecule is detected at high levels in a wide range of conditions from tumoral events to inflammatory events, septic states to obesity (4-7). A past experimental study, demonstrates that the endocan molecule plays a role in increasing tumor size (5). This may be related to endocan taking on vital duties during angiogenesis (8).

This study aimed to determine endocan molecule levels in patients with thyroid cancer, nodular goiter and thyroiditis. The levels of the endocan molecule in chronic inflammation and tumoral invasion stages were tried to be revealed. Thus, it was aimed to determine the availability of the endocan molecule in the differential diagnosis of thyroid diseases.

\section{MATERIAL AND METHOD}

This study was approved by the university /local human research ethics committee and all procedures performed in studies involving human participants were in accordance with the ethical standards of the institutional and/or national research committee and with the 1964 Helsinki declaration and its later amendments or comparable ethical standards. A prospective, cross-sectional clinical trial was designed. Approval for the study was obtained from the Clinical Research Ethics Committee with the decision dated 29.01.2018 and numbered 45/07.

The study was carried out between the 1st of March, 2018 and the 1st of August, 2018. During this period, a presentation about the study was made to patients who were to be operated on due to thyroid diseases. Patients who wanted to participate in the study voluntarily were included in the study. Patients with chronic diseases and patients who had undergone prior tumor surgery were excluded from the study. All the patients included in the study read and signed the information consent form, and their approval was obtained to procure their blood.

First, a total of 74 patients who were operated on during this period were included in the study, and blood samples were taken. However, two of these patients were excluded for the purpose of statistical evaluation and homogeneous grouping, due to pathology results. Medullary thyroid cancer was detected in one of these patients. In the other patient, beside the thyroid pathology, also a parathyroid adenoma was detected.

\section{Collection of Data}

Before surgery, a routine blood tube was used to collect $10 \mathrm{cc}$ of blood from each patient. Blood samples were centrifuged at $2000 \times \mathrm{g}$ (maximum RCF- relative centrifuge force) for approximately 10 minutes. Serum was aspirated using a pipette and stored at $-80^{\circ} \mathrm{C}$ for study. All serum collected in the specified period, was transferred to laboratory for measurement of serum endocan levels.

\section{Material Preparation Before Testing}

The components of the kit were removed from $+4^{\circ} \mathrm{C}$ and kept at room temperature for approximately 20 minutes. Serum samples were also taken from $-20^{\circ} \mathrm{C}$ and placed in the centrifuge. Before use, the samples were gently vortexed without creating any foam. 25x concentrated wash buffer was diluted to $1 \times$ working solution. The standard solution was prepared in seven dilutions from $2000 \mathrm{pg} / \mathrm{ml}$ to $31.25 \mathrm{pg} / \mathrm{ml}$. After which, the biotinylated solution was diluted from $100 \times$ to $1 \times$. Then, the $100 \times$ concentrated HRP (horseradish peroxidase) conjugate was diluted to $1 \times$. 


\section{Testing Procedure}

Standard solution or sample solution was added to each well and incubated at $37^{\circ} \mathrm{C}$ for 90 minutes. The liquid was then removed from each well. Following this, $100 \mu \mathrm{l}$. biotinylated detection antibody (ab) plate was incubated at $37^{\circ} \mathrm{C}$ for approximately 1 hour. Then, all wells were washed 3 times with a wash buffer. After washing, 100 $\mu \mathrm{l}$ of HRP conjugate was aspirated after 30 minutes of incubation and washed 5 times. After which, $90 \mu \mathrm{l}$ of substrate reagent was added to each well and incubated at $37^{\circ} \mathrm{C}$ for approximately 15 minutes. Finally, $50 \mu \mathrm{l}$ of stop solution was added to each well to stop the enzyme substrate reaction. The absorbance values of each well were measured (Molecular Device, Spectra Max, USA).

\section{Measurement of Serum Endocan Levels}

Serum endocan concentrations were measured using the manufacturer's protocol (Elab-science Human Endocan ELISA Kit; cat. No. E-EL-H1557 Elab-science, Wuhan, China). All samples and standards were tested three times $(n=3)$. A standard curve was created using seven dilutions of the Endocan standard solution and the amount of endocan was calculated using this standard curve.

\section{Creation of Study Groups}

According to the pathology reports four study groups were constituted:

Group 1: Patients operated on due to papillary thyroid cancer (PTC)

Group 2: Patients with nodular goiter on the background of thyroiditis (Thyroiditis)

Group 3: Multinodular goiter patients (MNG)

Group 4: Patients operated on due to follicular thyroid cancer (FTC).

\section{Statistical Analysis}

Continuous variables, means \pm standard deviation and categorical data were expressed as numbers and percentages. Data entry and analysis was done using Prism 8 software. Unpaired t-test was used to compare patient groups (benign, malignant, papillary thyroid carcinoma, follicular thyroid carcinoma, etc.). The differences between the groups were considered statistically significant at $\mathrm{p}<0.05$.

\section{RESULTS}

A total of 72 patients were included in the study. Of these, $62(86.11 \%)$ were female and only $10(13.89 \%)$ were male. The average age was measured as being 51.82 (2475 ) years. These patients were divided into four groups according to their pathology results. The number of patients in individual groups is shown in Table 1.
Table 1. Distribution of patient groups according to pathology results

\begin{tabular}{|lc|}
\hline Groups & Number of Patients \\
\hline Group 1: Papillary Thyroid Cancer (PTC) & $37(\% 51.39)$ \\
Group 2: Thyroiditis & $8(\% 11.11)$ \\
Group 3: Multinodular Goiter (MNG) & $20(\% 27.78)$ \\
Group 4: Follicular Thyroid Cancer (FTC) & $7(\% 9.72)$ \\
\hline
\end{tabular}

Statistical comparison results of the groups in terms of endocan levels are shown in Table 2. First, multiple comparisons of these four groups were made (Figure 1). However, through the multiple comparison, it was observed that there was no statistically significant difference between any of the groups $(\mathrm{p}=0.294)$.

Table 2. Statistical comparison results of the groups in terms of endocan levels

\begin{tabular}{|llcc|}
\hline & Groups & $\begin{array}{c}\text { Endocan levels } \\
(\mathbf{n g} / \mathbf{m l})\end{array}$ & P value \\
\hline & PTC & $0.140 \pm 0.052$ & \\
$\begin{array}{l}\text { Multiple analysis } \\
\text { of four groups }\end{array}$ & Thyroiditis & $0.136 \pm 0.063$ & $\mathrm{p}>0.050^{*}$ \\
& MNG & $0.112 \pm 0.047$ & \\
\hline FTC & $0.167 \pm 0.026$ & \\
$\begin{array}{l}\text { Comparison of } \\
\text { malign and benign }\end{array}$ & Benign & $0.121 \pm 0.051$ & \\
\hline Miseases & Malign & $0.148 \pm 0.043$ & $\mathrm{p}=0.0375^{\star}$ \\
Comparison of & PTC & $0.140 \pm 0.052$ & $\mathrm{p}=0.047^{*}$ \\
\hline PTC FTC & FTC & $0.167 \pm 0.026$ & \\
\hline
\end{tabular}

(PTC=Papillary thyroid cancer, FTC $=$ Follicular thyroid cancer, $\mathrm{MNG}=$ Multinodula goitre) ( ${ }^{*}$ Unpaired T test)

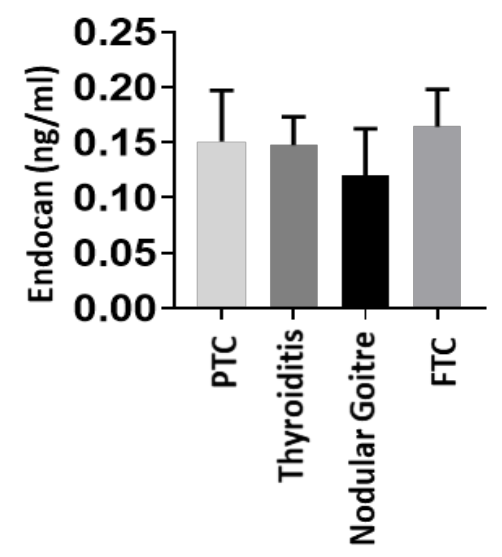

Figure 1. Multiple comparison results of patient groups classified according to different pathological findings.

Later, patients were divided into two classes; those reported as benign (Group $2+$ Group 3) and those reported as malignant (Group $1+$ Group 4) (Figure 2). In the classification made according to these features, the endocan levels in the malignant group were found to be statistically significant $(\mathrm{p}=0.0375)$. 


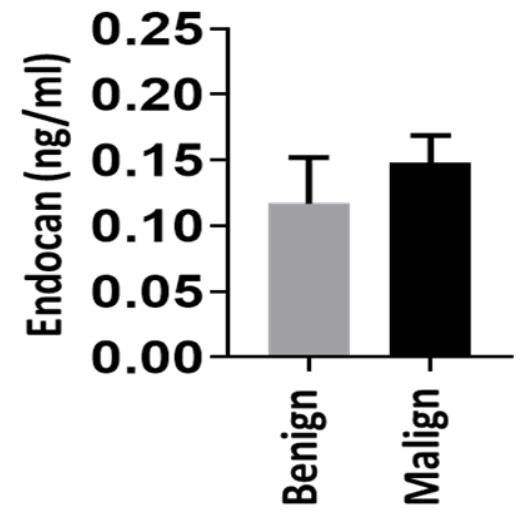

Figure 2. Comparison of benign and malign groups

Finally, the statistical difference in serum samples of PTC (Group 1) and FTC (Group 4) patients, the subtypes of thyroid carcinomas, were examined (Figure 3). As a result of the analysis, a high level of endocan was detected in FTC compared to PTC and this result was statistically significant $(\mathrm{p}=0.047)$.

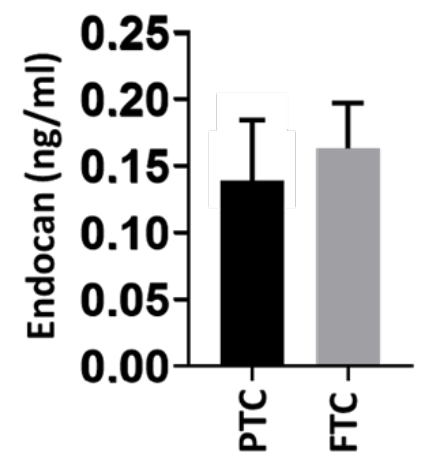

Figure 3. Papillary Thyroid Carcinoma versus Follicular Thyroid Carcinoma

\section{DISCUSSION}

The "endocan" molecule, otherwise known as endothelial cell-specific molecule-1 (ESM-1), is a proteoglycan found in vascular endothelial cells. It has been shown that vascular endothelial growth factor (VEGF) increases endocan activity, which in turn induces tumor formation (9). VEGF-dependent endocan secretion is severely impaired in endothelial cells treated with anti-angiogenic and multi tyrosine kinase inhibitors (10). There are many studies stating the importance of using endocan level as a biomarker in screening tests and defining the prognostic value in angiogenesis-targeted cancer treatments (11-17). In these studies, it is seen that endocan has an active role within the angiogenesis mechanism. In the literature, endocan levels have been shown to decrease in only a few studies on endocan levels of cancer patients (18). In fact, the data obtained from many of these studies, strengthen the view that the experimental evidence related to endocan, can be used as a suitable biomarker in clinical practice.

In a study where Ji et al. (16) compared patients with colorectal cancer (CRC) and healthy individuals, they determined that endocan levels increased significantly in patients with CRC and that endocan may be a potential serum marker for screening in the early period of CRC. In a study conducted by $\mathrm{H}$. Jiang et al. (13) on the Chinese population, where healthy individuals were compared with those having CRC, it was revealed that patients with CRC had high endocan levels. It has been shown that, this high level has a significant correlation with histological differentiation, TNM stage, tumor depth, and lymph node metastasis and it has been stated that the risk of death is significantly higher in patients with high endocan expression levels. In the light of these results, they made an assessment that the serum endocan level plays a role in the development and metastasis of cancer and may show prognostic signs in CRC.

Endocan plays a key role in cell adhesion regulation, inflammatory diseases and tumour growth. It interacts in cell growth and proliferation, particularly with insulinlike growth factor and its expression is induced by tumor necrosis factor-alpha (TNF- $\alpha$ ) and Interleukin-1 beta (IL-1 $\beta)(4,19)$. High endocan expression has been shown to correlate with poor prognosis and metastasis in various human cancers such as lung, breast, kidney, liver and brain cancer $(6,19-21)$. In this study as well, when the benign thyroid disease group and the malignant thyroid disease group were compared, the level of endocan was observed to be significantly higher in the malignant group. VEGF-dependent endocan secretion is induced in malignant diseases. This finding is in line with the studies referenced above, indicating that the endocan molecule can be used as a general tumor marker.

Noninvasive tests such as thyroid function tests, thyroid antibody levels, thyroid ultrasound, ultrasound elastography, thyroid scintigraphy are used in the differential diagnosis of thyroid nodules. However, the best test in the differential diagnosis of benign and malignant nodules is the invasive method, FNAB. Endocan serum level measurement seems to be a candidate to be used as a non-invasive method in the future, in the differentiation of malignant-benign nodules. Many studies highlighted that endocan is an appropriate biomarker of neoangiogenesis in cancers. The dermatan sulfate chain appears to have a vital role, in carrying out the duties of endocan in vascular and tumor growth. In a review study conducted by Delehedde et al, it was concluded that antiangiogenic treatments may be 
predictive, especially in cancers where neoangiogenesis is important in tumor growth. (25). In this study, when the endocan levels in PTC and FTC patients were compared, it was observed that the endocan level in FTC - which is known to spread by the hematogenous route and prefers invasion through blood vessels - was almost twice the level of PTC patients. This finding strongly supports the role of endocan in neoangiogenesis.

To date, opinions have been advocated indicating that endocan can be used as a marker in inflammatory diseases. In studies carried out by Arpac1 (22) and Güngör (23), it has been revealed that endocan elevation occurring as a result of endothelial dysfunction due to hypothyroidism, can be used as an early marker for cardiovascular diseases. In an article where Voiosu et al. compared patients with inflammatory bowel disease (IBD) with a healthy control group and stage 4 cancer patients, endocan levels were found to be significantly higher in patients in the IBD group than in the healthy control group and cancer patients. It has been concluded that in the future, endocan may be a potential biomarker in IBD patients (24). In this study, there was no statistically significant increase in patients with thyroiditis, although the serum endocan level was higher than that of MNG patients.

The weakest point of this study is undoubtedly the low number of patients. The main reason for this was that we had difficulty in finding sufficient financial support. Consequently, an equal distribution could not be achieved among the patient groups. This situation has caused some problems in terms of statistics. However, despite such limited conditions, the number of patients in the FTC group made up $9.72 \%$ of the total number of patients. Although studies with larger series are needed, we think that important data have been obtained as a result of this study.

\section{CONCLUSION}

In many cancers, the level of "endocan" in serum has increased in parallel with neoangiogenesis. It is also observed to increase in malignant thyroid diseases. This was particularly so in FTC, which shows spreading via the hematogenous route. Endocan serum level measurement seems to be a candidate to be used as a non-invasive method in the future, in the differentiation of malignant-benign nodules. This is an encouraging sign that the "endocan" molecule can be used as a general tumor marker. However, additional prospective studies with large randomized series are needed to determine the cut-off values of the molecule in question and to use it in clinical practice.

\section{ETHICAL DECLARATIONS}

Ethics Committee Approval: The study was carried out with the permission of Clinical Research Ethics Committee with the decision dated 29.01.2018 and numbered 45/07.

Informed Consent: Written informed consent was obtained from all participants who participated in this study.

Referee Evaluation Process: Externally peer-reviewed.

Conflict of Interest Statement: The authors have no conflicts of interest to declare.

Financial Disclosure: Scientific Research Project support was received from University of Health Sciences, Ankara Diskapi Yildirim Beyazit Training and Research Hospital.

Author Contributions: All of the authors declare that they have all participated in the design, execution, and analysis of the paper, and that they have approved the final version.

\section{REFERENCES}

1. Haugen BR, Alexander EK, Bible KC, Doherty GM, Mandel SJ, Nikiforov YE, et al. 2015 American Thyroid Association Management Guidelines for Adult Patients with Thyroid Nodules and Differentiated Thyroid Cancer: The American Thyroid Association Guidelines Task Force on Thyroid Nodules and Differentiated Thyroid Cancer. Thyroid. 2016 ;26:1-133.

2. Dogan L, Karaman N, Yilmaz KB, Ozaslan C, Atalay C. Total thyroidectomy for the surgical treatment of multinodular goiter. Surg Today. 2011;41:323-7.

3. Malloy, K.M. and M.F. Cunnane, Pathology and cytologic features of thyroid neoplasms. Surgical Oncology Clinics, 2008. 17: p. 57-70.

4. Lassalle P, Molet S, Janin A, Heyden JV, Tavernier J, Fiers W, et al. ESM-1 is a novel human endothelial cell-specific molecule expressed in lung and regulated by cytokines. J Biol Chem. 1996;271:20458-64.

5. Scherpereel A, Gentina T, Grigoriu B, Sénéchal S, Janin A, Tsicopoulos A, et al. Overexpression of endocan induces tumor formation. Cancer Res. 2003 ;63:6084-9.

6. Grigoriu BD, Depontieu F, Scherpereel A, Gourcerol D, Devos $\mathrm{P}$, Ouatas T, et al. Endocan expression and relationship with survival in human non-small cell lung cancer. Clin Cancer Res. 2006; 12:4575-82

7. Sarrazin S, Maurage CA, Delmas D, Lassalle P, Delehedde M. Endocan as a Biomarker of Endothelial Dysfunction in Cancer. Journal of Science and Therapy, vol. 2, no. 2, pp47-52, 2010.

8. Yang J, Yang Q, Yu S, Zhang X. Endocan: A new marker for cancer and a target for cancer therapy. Biomed Rep. 2015;3:279-283.

9. Shin JW, Huggenberger R, Detmar M. Transcriptional profiling of VEGF-A and VEGF-C target genes in lymphatic endothelium reveals endothelial-specific molecule- 1 as a novel mediator of lymphangiogenesis. Blood. 2008 ;112:2318-26.

10. Chen LY, Liu X, Wang SL, Qin CY. Over-expression of the Endocan gene in endothelial cells from hepatocellular carcinoma is associated with angiogenesis and tumour invasion. J Int Med Res. 2010;38:498-510. 
11. Lv Z, Fan Y, Chen H, Zhao D. Endothelial cell-specific molecule-1: a potential serum marker for gastric cancer. Tumour Biol. 2014;35: 10497-10502.

12. Liu N, Zhang LH, Du H, et al. Overexpression of endothelial cell specific molecule-1 (ESM-1) in gastric cancer. Ann Surg Oncol. $2010 ; 17: 2628-2639$.

13. Jiang H, Fu XG, Chen YT. Serum level of endothelial cell-specific molecule-1 and prognosis of colorectal cancer. Genet Mol Res. 2015; 14:5519-5526.

14. Kim JH, Park MY, Kim CN, et al. Expression of endothelial cellspecific molecule-1 regulated by hypoxia inducible factor-1alpha in human colon carcinoma: impact of ESM-1 on prognosis and its correlation with clinicopathological features. Oncol Rep. 2012;28:1701-1708.

15. Chang Y, Niu W, Lian PL, Wang XQ, Meng ZX, Liu Y, Zhao R. Endocan-expressing microvessel density as a prognostic factor for survival in human gastric cancer. World J Gastroenterol. 2016;22:5422-9.

16. Ji NY, Kim YH, Jang YJ, Kang YH, Lee CI, Kim JW, et al. Identification of endothelial cell-specific molecule-1 as a potential serum marker for colorectal cancer. Cancer Sci. 2010 ;101:2248-53.

17. Sagara A, Igarashi $K$, Otsuka $M$, Kodama A, Yamashita $M$, Sugiura R, et al. Endocan as a prognostic biomarker of triplenegative breast cancer. Breast Cancer Res Treat. 2017 ;161:269278 .

18. L. Zuo, S. M. Zhang, R. L. Hu et al., "Correlation between expression and diferentiation of endocan in colorectal cancer," World Journal of Gastroenterology, vol. 14, no. 28, pp. 562- 4568, 2008

19. Sarrazin S, Adam E, Lyon M, Depontieu F, et al. (2006). Endocan or endothelial cell specifc molecule-1 (ESM-1): a potential novel endothelial cell marker and a new target for cancer therapy. Biochim. Biophys. Acta 1765: 25-37.

20. Huang GW, Tao YM and Ding X (2009). Endocan expression correlated with poor survival in human hepatocellular carcinoma. Dig. Dis. Sci. 54: 389-394.

21. Maurage CA, Adam E, Mineo JF, Sarrazin S, et al. (2009). Endocan expression and localization in human glioblastomas. J. Neuropathol. Exp. Neurol. 68: 633-641.

22. Arpaci D, Karakece E, Tocoglu AG, Ergenc H, Gurol G, Ciftci $\mathrm{IH}$, et al. Endocan, TGF-beta, and ADMA as Risk Factors for Endothelial Dysfunction and Possible Vascular Disease in Patients with Subclinical Hypothyroidism. Ann Clin Lab Sci. 2016 ;46:601-607.

23. Gungor A, Palabiyik SS, Bayraktutan Z, Dursun H, Gokkaya $\mathrm{N}$, Bilen A, et al. Levels of endothelial cell-specific molecule-1 (ESM-1) in overt hypothyroidisim. Endocr Res. 2016 ;41:275280.

24. Voiosu T, Bălănescu P, Benguș A, Voiosu A, Baicuș CR, Barbu M, Ladaru A, et al. Serum endocan levels are increased in patients with inflammatory bowel disease. Clin Lab. 2014;60:505-10.

25. Delehedde M, Devenyns L, Maurage CA, Vivès RR. Endocan in cancers: a lesson from a circulating dermatan sulfate proteoglycan. Int J Cell Biol. 2013;2013:705027. 